\title{
Current and Emerging Options for the Management of Inherited von Willebrand Disease
}

\author{
Jessica M. Heijdra ${ }^{1}$ (D) Marjon H. Cnossen ${ }^{1}$ (D) Frank W. G. Leebeek ${ }^{2}$ (D)
}

Published online: 8 August 2017

(c) The Author(s) 2017. This article is an open access publication

\begin{abstract}
Von Willebrand disease (VWD) is the most common inherited bleeding disorder with an estimated prevalence of $\sim 1 \%$ and clinically relevant bleeding symptoms in approximately $1: 10,000$ individuals. VWD is caused by a deficiency and/or defect of von Willebrand factor (VWF). The most common symptoms are mucocutaneous bleeding, hematomas, and bleeding after trauma or surgery. For decades, treatment to prevent or treat bleeding has consisted of desmopressin in milder cases and of replacement therapy with plasma-derived concentrates containing VWF and Factor VIII (FVIII) in more severe cases. Both are usually combined with supportive therapy, e.g. antifibrinolytic agents, and maximal hemostatic measures. Several developments such as the first recombinant VWF concentrate, which has been recently licensed for VWD, will make a more "personalized" approach to VWD management possible. As research on new treatment strategies for established therapies, such as population pharmacokinetic-guided dosing of clotting factor concentrates, and novel treatment modalities such as aptamers and gene therapy are ongoing, it is likely that the horizon to tailor therapy to the individual patients' needs will be extended, thus, further improving the already high standard of care in VWD in most high-resource countries.
\end{abstract}

Frank W. G. Leebeek

f.leebeek@erasmusmc.nl

1 Department of Pediatric Hematology, Erasmus University Medical Center - Sophia Children's Hospital, Wytemaweg 80, 3015 CN Rotterdam, The Netherlands

2 Department of Hematology, Erasmus University Medical Center, Rotterdam, 's-Gravendijkwal 230, 3015 CE Rotterdam, The Netherlands

\section{Key Points}

Von Willebrand disease (VWD) is the most common inherited bleeding disorder and is mainly characterized by mucocutaneous bleeding and bleeding after trauma or surgery.

For decades, hemostatic treatment in VWD has consisted of desmopressin and plasma-derived von Willebrand factor (VWF)-containing concentrates.

Recently, the first recombinant VWF concentrate has been developed and licensed for treatment of VWD in the USA. As research on new treatment modalities is ongoing, it is likely that management of VWD patients can be improved further.

\section{Introduction}

Von Willebrand disease (VWD) is the most common inherited bleeding disorder with an estimated prevalence of $\sim 1 \%$ [1]. Clinically relevant bleeding symptoms are present in approximately 1:10,000 individuals [2]. VWD is caused by a quantitative and/or qualitative defect in von Willebrand factor (VWF).

\subsection{Function of von Willebrand Factor (VWF)}

VWF plays an important role in primary hemostasis. It circulates in the plasma in a globular, inactive form. When vascular damage occurs, VWF binds to the exposed 
vascular subendothelial collagen and uncoils. Once VWF is uncoiled, the binding site for platelet glycoprotein Ib $\alpha$ on the VWF A1 domain becomes exposed, allowing platelets to bind [3]. Concomitantly, platelets also bind to vascular collagen. After activation by thrombin and other agonists, platelets undergo shape changes and platelet integrin $\alpha I I b \beta 3$ (the GPIIb-IIIa complex) becomes able to bind VWF with high affinity, but also fibrinogen and fibronectin, leading to subsequent platelet aggregation [4].

\subsection{Pathophysiological Mechanisms in von Willebrand Disease (VWD)}

The function of VWF and pathophysiology of VWD is better understood if the different phases of VWF-synthesis, -secretion, and -clearance are taken into account.

\subsubsection{Synthesis of VWF}

VWF is synthesized in endothelial cells and megakaryocytes. The protein pre-pro-VWF is produced after primary translation and glycosylation of mRNA by ribosomes in the endoplasmic reticulum of endothelial cells and megakaryocytes. This protein includes a signal peptide, a large propeptide and the mature VWF subunit, which is composed of several structural domains, named A to D. After cleavage of the signal peptide, the VWF subunits dimerize and are transported into the Golgi apparatus, where disulfide bridges are formed between the D3 domains. This leads to formation of VWF multimers. The propeptide is subsequently cleaved but remains noncovalently bound to the forming VWF multimer, facilitating the disulfide bond formation. These ultra large VWF multimers are the most hemostatically potent multimers [5].

\subsubsection{Secretion of $V W F$}

After synthesis, up to $95 \%$ of VWF is secreted constitutively into the circulation, whereas the remainder is stored in Weibel-Palade bodies in the endothelium, and in platelet $\alpha$-granules [6]. Adrenergic stress, thrombin generation, or treatment with desmopressin (DDAVP) stimulates the release of stored VWF [7]. After secretion, the ultra large multimers are proteolyzed by ADAMTS13-a disintegrin and metalloproteinase with a thrombospondin type 1 motif, member 13-into smaller multimers that circulate in plasma [8].

\subsubsection{Clearance of VWF}

After secretion of VWF into the circulation, the survival of the VWF multimers depends on their size, interaction with platelets and other cells, susceptibility to proteolysis, and the rate of clearance from the circulation [9]. These mechanisms of VWF clearance are not yet fully understood. Abnormal clearance of VWF may also contribute to the pathogenesis of VWD, as several gene mutations have been identified that are specifically associated with increased clearance of endogenous VWF [10].

\subsection{Epidemiology and Diagnosis}

Patients are diagnosed based on a personal or family history of bleeding and laboratory abnormalities in VWF, Factor VIII (FVIII), or both. VWD is classified into three types. Type 1 , which accounts for $70-80 \%$ of cases, is a partial quantitative deficiency of von Willebrand factor due to either reduced production and/or secretion, or increased clearance of VWF. Type 2, which accounts for approximately $20 \%$ of cases, includes several qualitative defects of VWF defined as subtypes $2 \mathrm{~A}, 2 \mathrm{~B}, 2 \mathrm{M}$, and $2 \mathrm{~N}$. Type 3 (accounting for $<5 \%$ of cases) is defined as a virtually complete absence of VWF, making this the most severe type of VWD (Table 1) [9].

To systematically quantify the bleeding symptoms in an individual, bleeding scores may be a helpful diagnostic tool [11]. Different bleeding questionnaires have been developed over the years, but since 2010, the International Society for Thrombosis and Hemostasis Bleeding Assessment Tool (ISTH-BAT), intended for use in both adults and children, is recommended [12]. This questionnaire scores 14 different bleeding symptoms on a scale of $0-4$. The values for an abnormal bleeding score are $\geq 3$ in children, $\geq 4$ for adult males and $\geq 6$ for adult females [13]. A limitation of the score is that it is a cumulative score, which means that the score is age dependent, can be saturated, and that bleedings in the past may reveal a high bleeding score, which may not reflect the current bleeding phenotype.

Key measurements in the evaluation of VWD include VWF Ristocetin Cofactor (VWF:RCo), which measures the ability of VWF to interact with platelets; VWF antigen (VWF:Ag), as a measure of the total amount of VWF; and FVIII, which reflects the ability of VWF to chaperone FVIII through the circulation. According to most guidelines, in order to establish a definite diagnosis of type $1 \mathrm{VWD}$, a patient requires VWF:RCo levels $<0.30 \mathrm{IU} / \mathrm{ml}$ and a ratio of VWF:RCo to VWF antigen (VWF:Ag) $>0.6$. Patients with a bleeding tendency and VWF:RCo levels of $0.30-0.50 \mathrm{IU} / \mathrm{ml}$ are regarded as individuals with "low VWF levels," which are considered a risk factor for bleeding [5]. Patients with type 2 VWD have VWF:RCo levels $<0.30 \mathrm{IU} / \mathrm{ml}$ and a VWF:RCo to VWF:Ag ratio or a FVIII to VWF:Ag ratio of $\leq 0.60$. Type $2 \mathrm{~N}$, which is characterized by a reduced binding of FVIII to VWF, shows low FVIII levels and a reduced FVIII to VWF:Ag ratio. A patient is diagnosed with type 3 VWD when VWF:Ag is $<0.05 \mathrm{IU} / \mathrm{ml}$. 
Table 1 Von Willebrand disease (VWD) classification according to the International Society on Thrombosis and Hemostasis [9]

\begin{tabular}{lll}
\hline Type of VWD & Description & $\%$ of total VWD population (\%) \\
\hline 1 & Partial quantitative deficiency of VWF & $70-80$ \\
2 & Qualitative VWF defects & $\sim 20$ \\
2A & $\begin{array}{l}\text { Decreased VWF-dependent platelet adhesion and a deficiency of high- } \\
\text { molecular-weight VWF multimers } \\
\text { 2B }\end{array}$ & $\begin{array}{l}\text { Increased affinity for platelet glycoprotein Ib (GpIb) and a deficiency of high- } \\
\text { molecular-weight VWF multimers }\end{array}$ \\
$2 \mathrm{M}$ & $\begin{array}{l}\text { Decreased VWF-dependent platelet adhesion without a deficiency of high- } \\
\text { molecular weight VWF multimers }\end{array}$ \\
$2 \mathrm{~N}$ & Markedly decreased binding affinity for FVIII & $<5$ \\
3 & Virtually complete deficiency of VWF
\end{tabular}

$V W F$ von Willebrand factor

\subsection{Clinical presentation and Complications}

The most common symptoms in VWD patients are mucocutaneous bleedings, such as epistaxis $(\sim 50 \%)$, oral cavity bleeding $(\sim 60 \%)$, hematomas, and bleeding from minor wounds $(\sim 80 \%)$. In women, menorrhagia is often present, eventually leading to iron-deficiency anemia necessitating iron administration or blood transfusions in some cases [14]. The risk of severe post-partum hemorrhage is increased, especially in women with low factor levels in the third trimester. This risk remains higher than in healthy women, despite specialized treatment [15]. One of the most difficult complications to manage is gastrointestinal bleeding, which occurs mainly in elderly type 2A and type 3 VWD patients. Most commonly, gastrointestinal bleeding is caused by angiodysplasia, although it is difficult to establish this diagnosis. Joint and muscle bleeding are rare, although these may be underestimated complications, as in a recent study $23 \%$ of moderate and severe VWD patients reported joint bleeding [16]. Bleeds in joints and muscles are explained by the fact that VWF functions as chaperone protein of FVIII, protecting FVIII from proteolysis in the circulation. Therefore, severe deficiency of VWF causes a concomitant deficiency of FVIII. Patients with both a severe VWF and FVIII deficiency may present with joint bleeds, which are more typical for hemophilia and may cause long-term impairment.

Bleeding symptoms leading to a diagnosis of VWD often present peri- or postoperatively or after dental procedures in index patients. When this occurs, a family history should be taken subsequently and a hemostatic workup should be performed evaluating both the primary and the secondary hemostasis, and should include laboratory evaluation of VWF and FVIII levels in order to identify hemostatic abnormalities [11].

\subsection{Inheritance and Molecular Genetics}

There is a large variation in mutations described in VWD. Quantitative deficiencies of VWF as observed in severe type 1 and type 3 are mostly caused by null alleles (large gene deletions, stop codons, frameshift mutations, or splice-site mutations), but may also be caused by mutations in the promotor regions of the VWF gene [17, 18]. Type 3 patients are usually homozygous or compound heterozygous for these defects [19]. Type 1 VWD is mostly caused by heterozygous missense mutations $[17,20,21]$. However, in approximately $30 \%$ of type 1 VWD patients, no mutations in the VWF gene are identified [20, 21]. Type 2 VWD is characterized by missense mutations, which are located in the affected functional domain. The inheritance of subtypes $2 \mathrm{~A}, 2 \mathrm{~B}$, and $2 \mathrm{M}$ is autosomal dominant. Type $2 \mathrm{~N}$ VWD has a recessive inheritance pattern and is caused by homozygosity for two type $2 \mathrm{~N}$ mutations, or compound heterozygosity, with a type 1 defect and a type $2 \mathrm{~N}$ defect [22].

\subsection{Variation in VWF Levels}

It is well known that even in individuals with similar gene mutations, plasma VWF levels show a large intra- and interindividual variability. A major determinant of interindividual variation in VWF levels is $\mathrm{ABO}$ blood group, as VWF plasma levels are approximately $25 \%$ lower in individuals with blood group $\mathrm{O}$, when compared to non$O$ individuals [23]. In these individuals, an increased clearance is described, possibly regulated by the $\mathrm{ABO}$ blood group antigens on $\mathrm{N}$-linked oligosaccharides of VWF [24].

Genome-wide association studies (GWAS) have also identified several other genetic loci that are associated with VWF levels in healthy individuals. Mutations or poly- 
morphisms in these loci may explain variability in VWF levels between individuals with VWD but also the varying bleeding phenotype in patients without variations or mutations in the gene coding for VWF. C-type lectin domain family 4 member M (CLEC4M) and Lipoprotein Receptor 1 (LRP1) have been associated with VWF clearance $[25,26]$, and Syntaxin Binding Protein 5 (STXBP5) seems to affect VWF exocytosis [27]. New candidate genes for VWF levels found in GWAS include SCARA5, STAB2, STX2, TC2N, and UFM1 [27, 28]. Recently, a linkage analysis identified a highly significant quantitative trait locus (QTL) on chromosome 2 that was not detected earlier by large GWAS. The effect size on VWF variation of this locus was comparable to the effect of the ABO locus (19.2 vs. 24.5\%) [29]. The effect mechanism of this genetic variant has not yet been elucidated.

Besides these endogenous factors (blood group, gene mutations, and modifying genetic loci), many exogenous factors have been identified that clearly influence VWF levels, such as physical exercise, stress, inflammation, hypertension, diabetes, hormones, and pregnancy [30-33]. Moreover, VWF levels also increase with age, possibly explained by increasing arterial rigidity over time [34, 35]. All these different factors lead to challenges in establishing normal and abnormal VWF levels in individuals with and without a clinically significant bleeding phenotype.

\section{Current Treatment Options}

In this review article, we aim to give an overview of current treatment in congenital VWD. Firstly, we will discuss treatment for acute bleeding events and how to prevent bleeding during surgical and dental procedures ("on-demand" treatment). Secondly, we will discuss "prophylactic" treatment, which aims to prevent spontaneous bleeding in VWD patients who experience frequent and severe bleeding. Furthermore, we will elaborate on novel developments and future perspectives with regard to treatment of this frequently diagnosed bleeding disorder.

The goal of treatment in VWD patients is to stop or prevent bleeding by increasing plasma VWF and FVIII levels to adequate hemostatic levels by stimulation of the release of endogenous VWF by administration of DDAVP, or by infusing VWF-containing factor concentrates. Choice of treatment is dependent on the type of disease and the severity of the bleeding. A multidisciplinary approach involving a (pediatric) hematologist and other specialists, such as (orthopedic) surgeon, gynecologist, anesthesiologist, or clinical geneticist is of course dependent on the specific hemostatic challenge and situation, but is of great importance to provide optimal care for the individual VWD patient.

\subsection{Desmopressin (DDAVP)}

Desmopressin (1-deamino-8-d-arginine vasopressin, DDAVP) is a synthetic vasopressin analogue. The drug increases VWF and FVIII plasma levels by releasing VWF from Weibel-Palade bodies in the endothelium [7]. Due to this effect, it is the most widely used drug in the treatment of VWD.

DDAVP can be administered intravenously or subcutaneously at a standardized dose of $0.3 \mu \mathrm{g} / \mathrm{kg}$ every $12-24 \mathrm{~h}$. Although some groups have suggested the use of a capped dose of 15 or $20 \mu \mathrm{g}$, further research is warranted to prove the effectiveness of this concept $[36,37]$. DDAVP is also available as an intranasal spray, often used for home treatment in case of bleeding. Intranasal dosing is $150 \mu \mathrm{g}$ (one puff) in patients $<50 \mathrm{~kg}$ or $300 \mu \mathrm{g}$ (two puffs) in patients $\geq 50 \mathrm{~kg}$. Due to variable adsorption in case of intranasal administration, an increase in VWF and FVIII may be lower than after intravenous or subcutaneous administration [38].

Interindividual response to DDAVP differs greatly. Most type 1 VWD patients respond well to DDAVP. In type 2 VWD, responsiveness to DDAVP varies significantly and is difficult to predict. Understandably, type 3 VWD patients are unresponsive as they have little to no endogenous VWF to mobilize. Individual characteristics such as VWF gene mutation and baseline VWF:Ag and VWF:RCo levels have been reported to influence the increase of VWF and FVIII plasma levels and duration of response [39]. In general, response in the individual patient has been proven to be reproducible and consistent over time [40]. However, it is important to realize that DDAVP response decreases when DDAVP is administered sequentially at short intervals (tachyphylaxis) due to depletion of VWF storage in the endothelium [41].

Due to the great interpatient variability in response, a DDAVP test is required to establish DDAVP response in each individual patient. Different protocols dictate different blood sampling regimens, but there is general agreement that plasma levels of VWF and FVIII should be measured prior to, and at least 1 (peak level) and $4 \mathrm{~h}$ after DDAVP infusion. According to most investigators, a patient is defined as responsive to DDAVP when VWF and FVIII levels increase at least two- to threefold and VWF and FVIII levels are $>0.30 \mathrm{IU} / \mathrm{ml} 30-90 \mathrm{~min}$ after DDAVP administration $[42,43]$. In most patients with rapid clearance of VWF, the initial response to DDAVP is substantial. However, VWF and FVIII levels may decrease to inadequate levels within several hours when the half-life of VWF and FVIII is short [44]. Therefore, whether DDAVP is an adequate treatment option is dependent on both the type and the severity of the bleeding or surgical procedure as well as on the initial response and duration of response. 
In individuals with type $2 \mathrm{~B}$ VWD, DDAVP treatment is contraindicated because of aggravation of the tendency towards thrombocytopenia [45].

DDAVP is considered safe but may have mild side effects, such as flushing, transient headache, or hypotension [46]. To prevent occurrence of more severe side effects such as hyponatremia and cardiovascular events, fluid intake should be restricted to $1500 \mathrm{ml}$ during the first $24 \mathrm{~h}$ after administration of the drug. This applies for pediatric patients eligible for DDAVP with a body weight $>20 \mathrm{~kg}$ and adult patients without adjusting for body weight. Due to the risk of side effects, in very young $(<4$ years) and older ( $>70$ years) patients desmopressin should be used with caution [47]. The use of DDAVP in pregnant women also remains controversial due to the lack of evidence of safety and efficacy in this group. Several cases have been reported, describing complications such as hyponatremia, pre-term delivery, and uterine contractions in this patient group [48].

\subsection{Plasma-Derived Factor Concentrates}

Until the 1980s, patients unresponsive to DDAVP were usually treated with cryoprecipitate. The emergence of virally-inactivated FVIII concentrates containing VWF for the treatment of hemophilia A proved a more optimal therapeutic option for patients with VWD.
Those eligible for treatment with plasma-derived factor concentrates are type 3 VWD patients who do not produce any endogenous VWF, and type 2B VWD patients in whom DDAVP can cause thrombocytopenia. Furthermore, factor concentrates are used in patients with type 1 and type 2 VWD who are insufficiently responsive to DDAVP, or patients with contraindications for DDAVP therapy. VWF/FVIII concentrates can be administered in case of bleeding or surgery, but also as prophylaxis in severe VWD patients with recurrent spontaneous bleeding, including joint bleeds, gastrointestinal bleeds in the elderly, and severe epistaxis in children.

Nowadays, several plasma-derived, virally inactivated factor concentrates containing VWF and FVIII are licensed for treatment of VWD. However, the availability of replacement therapy for bleeding disorders in general is strongly dependent on the economic situation and healthcare organization in countries. As in most severe cases VWF as well as FVIII levels are decreased, both factors often require substitution. The different available products contain different ratios of VWF and FVIII, with differences in specific activity (Table 2) [49-51]. Therefore, before treating a patient with a VWF/FVIII concentrate, the specific activity and the VWF:RCo/VWF:Ag and VWF:RCo/FVIII ratios should be considered.

For on-demand treatment, calculation of the required dose of VWF or FVIII is based on the empirical finding that 1 IU VWF:RCo per kg body weight raises VWF with

Table 2 Von Willebrand factor containing concentrates for the treatment of von Willebrand disease tested in prospective clinical studies

\begin{tabular}{|c|c|c|c|c|c|c|}
\hline Product & Manufacturer & Preparation & Purification & Viral inactivation & $\begin{array}{l}\text { Ratio VWF:RCo/ } \\
\text { VWF:Ag }\end{array}$ & $\begin{array}{l}\text { Ratio } \\
\text { VWF:RCo/ } \\
\text { FVIII }^{\mathrm{a}}\end{array}$ \\
\hline Alphanate & Grifols & PD & Heparin ligand chromatography & $\mathrm{S} / \mathrm{D}+$ dry heat & $0.47 \pm 0.1$ & $0.91 \pm 0.2$ \\
\hline Factor $8 \mathrm{Y}$ & $\begin{array}{l}\text { Bioproducts } \\
\text { Laboratory }\end{array}$ & PD & Heparin/glycine precipitation & S/D + dry heat & 0.29 & 0.81 \\
\hline Fanhdi & Grifols & $\mathrm{PD}$ & Heparin ligand chromatography & S/D + dry heat & $0.47 \pm 0.1$ & $1.04 \pm 0.1$ \\
\hline $\begin{array}{l}\text { Humate-P } \\
\text { (US) }\end{array}$ & CSL Behring & $\mathrm{PD}$ & Multiple precipitation & Pasteurization & $0.59 \pm 0.1$ & $2.45 \pm 0.3$ \\
\hline \multicolumn{7}{|l|}{$\begin{array}{l}\text { Haemate P } \\
\text { (EU) }\end{array}$} \\
\hline Immunate & Shire & PD & Ion-exchange chromatography & $\mathrm{S} / \mathrm{D}+$ vapor heat & 0.47 & 1.1 \\
\hline $\begin{array}{c}\text { Koate- } \\
\text { DVI }\end{array}$ & $\begin{array}{l}\text { Kedrion } \\
\text { Biopharma }\end{array}$ & PD & $\begin{array}{l}\text { Multiple precipitation }+ \text { size } \\
\text { exclusion chromatography }\end{array}$ & $\mathrm{S} / \mathrm{D}+$ dry heat & 0.48 & 1.1 \\
\hline Voncento & CSL Behring & PD & $\begin{array}{l}\text { Heparin/glycine precipitation } \\
+ \text { gel filtration chromatography }\end{array}$ & $\mathrm{S} / \mathrm{D}+$ dry heat & $0.87-0.95$ & 2.0 \\
\hline Vonvendi & Shire & $\operatorname{Rec}$ & - & - & $>1$ & $>10$ \\
\hline Wilate & Octapharma & $\mathrm{PD}$ & $\begin{array}{l}\text { Ion-exchange }+ \text { size exclusion } \\
\text { chromatography }\end{array}$ & $\mathrm{S} / \mathrm{D}+$ dry heat & - & 0.9 \\
\hline Wilfactin & LFB & $\mathrm{PD}$ & $\begin{array}{l}\text { Ion-exchange }+ \text { affinity } \\
\text { chromatography }\end{array}$ & $\begin{array}{l}\text { S/D + nanofiltration } \\
\quad+\text { dry heat }\end{array}$ & 0.7 & 60 \\
\hline
\end{tabular}

$P D$ plasma derived, $R e c$ recombinant, $S / D$ solvent detergent

${ }^{a}$ Data derived from [49-51] 
$\sim 1.5 \%$ and 1 IU FVIII:C per kg raises FVIII plasma level by $\sim 2 \%$. Dosing is based on both VWF:RCo and FVIII:C levels. The aim is to increase or normalize both factor levels in order to ensure adequate hemostasis. The more recent applicability of quickly available results of VWF:RCo or VWF:GPIbM assays has greatly improved and facilitated VWF/FVIII concentrate dosing [52].

In case of treatment with bolus infusions, the required dose is determined using the following formula: Required IU of VWF concentrate (based on VWF:RCo content $)=$ body weight $(\mathrm{kg}) \times$ desired VWF:RCo rise $(\%)$ $(\mathrm{IU} / \mathrm{dl}) / 1.5$. In case of continuous infusion, the initial infusion rate is calculated as follows: Infusion rate (IU/kg/ $\mathrm{h})=$ clearance $(\mathrm{ml} / \mathrm{kg} / \mathrm{h}) \times$ desired steady state level (IU/ $\mathrm{ml})$. Continuous infusion is feasible, as Lubetsky et al. described that in their study, reconstituted Humate $\mathrm{P}$ was stable for 14 days at room temperature [53].

In principle, the endogenous FVIII synthesis in VWD patients is normal. The low FVIII plasma concentrations are the result of low VWF and/or decreased binding affinity of VWF for FVIII. When exogenous VWF is infused, it binds and stabilizes FVIII, thereby increasing the FVIII plasma level. Furthermore, clearance of FVIII is known to be lower than that of VWF [54]. Subsequently, VWF/FVIII concentrate infusions in a short time period may lead to very high FVIII:C plasma concentrations $(>2.70 \mathrm{IU} / \mathrm{ml})$, and thus form a possible risk factor for thromboembolic complications [55-57]. Therefore, daily measurements of plasma FVIII levels after surgery are important in patients receiving repeated doses of VWF/FVIII concentrate not only to assess the risk of bleeding but also to monitor the risk of thrombosis. The terminal half-life of VWF:Ag and VWF:RCo differs greatly between patients [58]. Monitoring of VWF:RCo levels intraoperatively and during the first postoperative days is important to determine timing and dosing of the follow-up bolus infusions to ensure hemostatically adequate levels of VWF in the first phases of wound healing (Table 3) [1, 14, 52, 59]. For a treatment algorithm for bleeding and dental and surgical procedures with VWF/FVIII concentrates according to the National Heart, Lung and Blood Institute (NHLBI), see Fig. 1.

In theory, a product with a VWF/FVIII ratio of approximately $1: 1$ is the easiest to dose, because the rise of VWF and FVIII plasma levels after infusion can be easily predicted $[60,61]$. However, although no randomized trials have been performed, all different products with different ratios show good to excellent hemostatic properties in observational clinical studies [62,63]. Moreover, there is broad clinical experience in treatment of VWD patients with Humate- $\mathrm{P}^{\circledR}$ - the first virus-inactivated VWF/FVIII concentrate- which has been on the market for more than 30 years [64].

The rationale for treatment with highly purified concentrates containing nearly no FVIII or treatment with recombinant VWF is that patients with VWD all have normal production of FVIII, but lack adequate VWF levels to protect FVIII from degradation. When VWF levels are normalized by infusion of exogenous VWF, a subsequent rise of endogenous FVIII is expected. However, the rise of FVIII after infusion is slow and a peak is achieved only after $6-8 \mathrm{~h}$ [65]. Therefore, patients with low circulating FVIII levels require a priming dose of FVIII in addition to the VWF concentrate when hemostasis needs to be corrected promptly. In case of elective surgery, a VWF concentrate infusion should be administered at least $6-8 \mathrm{~h}$ before the operation to allow FVIII to rise to adequate levels in time for the procedure when no additional FVIII is administered.

Table 3 Recommendations for FVIII and von Willebrand factor (VWF) target levels in minor and major surgical and dental procedures according to a selection of guidelines

\begin{tabular}{|c|c|c|c|c|c|c|}
\hline \multirow[t]{2}{*}{ Guideline } & \multicolumn{3}{|l|}{ Minor procedures } & \multicolumn{3}{|l|}{ Major procedures } \\
\hline & $\begin{array}{l}\text { FVIII target levels } \\
\text { (IU/ml) }\end{array}$ & $\begin{array}{l}\text { VWF:RCo target } \\
\text { levels (IU/ml) }\end{array}$ & $\begin{array}{l}\text { Duration } \\
\text { (days) }\end{array}$ & $\begin{array}{l}\text { FVIII target levels } \\
\text { (IU/ml) }\end{array}$ & $\begin{array}{l}\text { VWF:RCo target } \\
\text { levels (IU/ml) }\end{array}$ & $\begin{array}{l}\text { Duration } \\
\text { (days) }\end{array}$ \\
\hline \multirow[t]{2}{*}{ NHLBI (US) [1] } & nd & $>1.00$ & Perioperative & nd & $>1.00$ & Perioperative \\
\hline & $>0.50$ & $>0.50$ & $3-5$ & $>0.50$ & $>0.50$ & $7-14$ \\
\hline AICE (Italy) [59] & $>0.30$ & nd & $2-4$ & $>0.50$ & nd & $5-10$ \\
\hline \multirow{3}{*}{$\begin{array}{l}\text { NVHB (the } \\
\text { Netherlands) [14] }\end{array}$} & $>0.80$ & $>0.80$ & Perioperative & $>0.80$ & $>0.80$ & Perioperative \\
\hline & $>0.50$ & nd & 3 & $>0.50$ & nd & $7-10$ \\
\hline & $>0.30$ & nd & $4-7$ & & & \\
\hline \multirow[t]{2}{*}{ UKHCDO (UK) [52] } & $>0.50$ & $>0.50$ & nd & $\geq 1.00$ & nd & Perioperative \\
\hline & & & & $>0.50$ & $>0.50$ & $6-10$ \\
\hline
\end{tabular}

NHLBI National Heart, Lung and Blood Institute, AICE The Italian Association of Hemophilia Treatment Centers, NVHB Dutch Society for Hemophilia Treaters, UKHCDO United Kingdom Haemophilia Centre Doctors' Organisation, $n d$ not defined in guidelines 


\section{Loading dose}

in VWF:RCo IU/ml
Target trough levels Maintenance dose

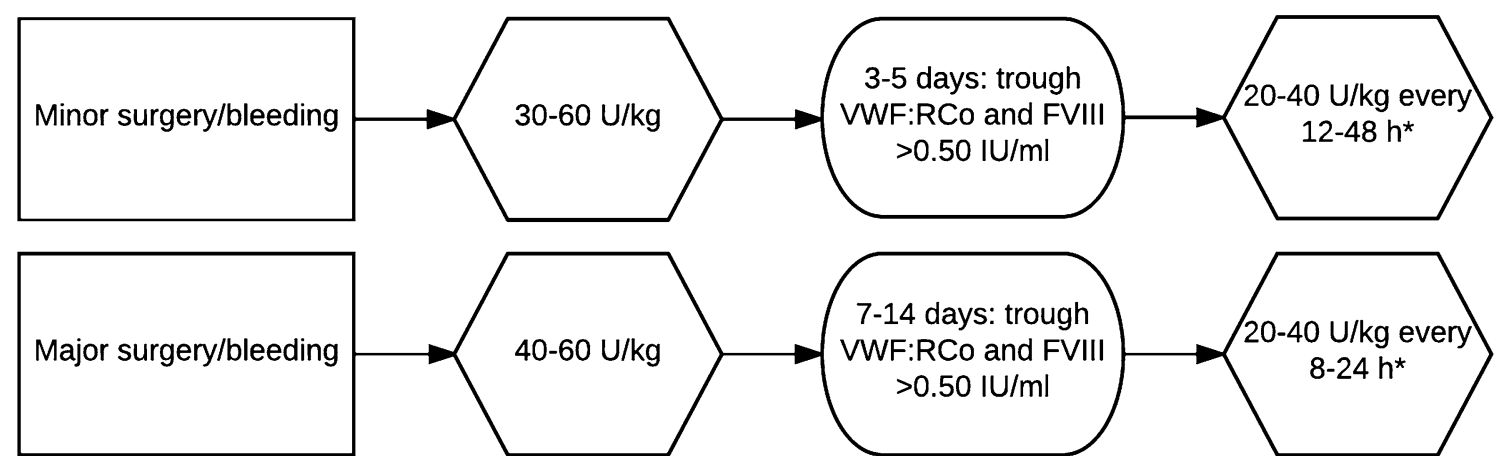

Fig. 1 Treatment of bleeding and dental and surgical procedures with VWF/FVIII concentrate according to National Heart, Lung and Blood Institute (NHLBI) [1]

\subsection{Treatment in Patients with Alloantibodies}

Alloantibodies against VWF are a rare complication in VWD, with an estimated prevalence of $6-10 \%$ in type 3 VWD patients [66, 67]. Almost all cases occur in type 3 VWD patients with partial or complete VWF gene deletions [68, 69], although a case of alloantibodies in a type 2B VWD patient has recently been described [70].

Patients with antibodies against VWF generally present with an impaired response to infused VWF-containing concentrates. When re-exposed to VWF, some patientsespecially those with high-titer alloantibodies-may develop severe anaphylactic reactions [71, 72]. Recombinant FVIII has been used successfully for hemostatic therapy in patients with anti-VWF antibodies. Due to the lack of stabilization by VWF, the half-life of FVIII is decreased. This problem can be overcome by continuous infusion of higher doses of FVIII concentrate [67]. Another option is treatment with recombinant Factor VIIa (rFVIIa) or activated prothrombin complex, which functions as a FVIII and Factor IX (FIX) bypassing agent [73-75]. These are regularly used to treat hemophilia patients with inhibiting antibodies. To extrapolate this experience to VWD patients with inhibiting antibodies seems reasonable, but sparse evidence for effectiveness and safety of rFVIIa treatment in patients with anti-VWF antibodies requires caution with regard to these products.

Immune tolerance induction (ITI) therapy, using high doses of factor concentrates and immunosuppressive therapy, is widely applied in hemophilia A. A case report of a 20-year-old male with alloantibodies to VWF treated with ITI was published in 2012. After 3 years of ITI treatment, inhibiting antibodies could still not be detected anymore, but the half-life of VWF-containing concentrates did not normalize [76]. Therefore, on the basis of this sporadic evidence, more research is required to assess safety and efficacy of ITI in VWD patients, especially as anaphylactic reactions may occur in this setting.

\subsection{Recombinant VWF Concentrate}

For patients with hemophilia, recombinant coagulation factor concentrates have been available for nearly two decades. These products reduce the transfer risk of viral infections and potentially other infectious agents. Another advantage is the independence of donor availability for the supply of plasma-derived concentrates. For VWD, Turecek and co-workers have recently developed a recombinant VWF (Vonicog alfa, rVWF) that is produced in genetically altered CHO cells expressing both VWF and FVIII [77]. As VWF is synthesized in the absence of the VWF protease ADAMTS13, this rVWF contains intact high molecular weight and ultra large multimers, resulting in a higher specific activity (ratio VWF:RCo:VWF:Ag $>1.0$ ) than in plasma-derived VWF concentrate. In 2013 Mannucci et al. reported a phase 1 trial to study the pharmacokinetic parameters of this product. The terminal half-life of of rVWF was comparable to that of plasma-derived VWF [78]. In a recent phase 3 clinical study on the treatment of bleeding episodes in patients with severe type1, 2, or 3 VWD, rVWF showed a high efficacy in cessation of bleeding [79]. The first dose of rVWF was administered together with rFVIII and subsequently without rFVIII. The outcome of treatment was rated as excellent in over $96 \%$ of bleeding episodes. Additional pharmacokinetic studies showed that FVIII normalized after sole infusion of rVWF within $6 \mathrm{~h}$. Treatment was considered safe, as no thrombosis, allergic reactions, or development of inhibitors to rVWF were demonstrated. Currently, studies are ongoing on the efficacy of rVWF in surgery, as well as studies on the use of long-term prophylaxis with rVWF concentrate in patients suffering from recurrent bleeding. Recently rVWF 
has been registered and approved for clinical use in the USA for the treatment of bleedings in adults with VWD.

\subsection{Supportive Treatment}

\subsubsection{Antifibrinolytic Agents}

Antifibrinolytic agents such as tranexamic acid and aminocaproic acid inhibit the interaction of plasminogen with fibrin, thus preventing the degradation of the fibrin clot. These agents are especially effective in the mucosa due to the high fibrinolytic activity present in these tissues [80]. Therefore, in case of mucocutaneous bleeding, supportive treatment with antifibrinolytics is strongly recommended in the light of the low cost and few side effects. The hemostatic effectiveness of tranexamic acid has also been demonstrated in large placebo-controlled randomized trials in patients undergoing high-risk cardiac or orthopedic surgery [81-83]. In patients with bleeding disorders undergoing surgical or dental procedures, antifibrinolytics are widely used to prevent perioperative blood loss. Although evidence from randomized controls is lacking for efficacy in VWD, this is generally accepted to be likely [84].

Antifibrinolytic agents can be administered systemically as an oral or intravenous formulation, or topically, as a mouthwash (for available formulations, concentrations, and dose see Table 4). Importantly, hematuria of unknown origin or caused by renal or ureteral bleeding is a contraindication for antifibrinolytic treatment as treatment of blood loss in the urinary tract may lead to clotting in the ureters and subsequent painful colic episodes with risk of ureter obstruction $[85,86]$.

\subsubsection{Hormonal Treatment}

Menorrhagia is a very common symptom in women with VWD, with a prevalence of $62-81 \%$ [87-89]. In women with VWD presenting with menorrhagia, it is important to first rule out anatomic and hormonal causes. Thereafter, hormonal treatment with oral contraceptives containing both progestin and estrogen can be initiated if there is no wish for pregnancy. Oral contraceptive treatment leading to non-ovulatory bleeding will significantly reduce uterine blood loss during the oral contraception-free week. When administered continuously ( $\geq 28$ days), total bleeding days can be reduced drastically [90].

Another hormonal treatment option is the levonorgestrel intrauterine device (IUD). This device suppresses endometrium and spiral arteriole growth and increases capillary thrombosis. It also has no effect on endometrial FVIII activity, while copper-containing intrauterine devices have been described to decrease FVIII activity [91]. In a study in 16 women with bleeding disorders receiving a levonorgestrel IUD, nine women became amenorrhoeic, and the remaining seven reported a significant decrease in menstrual blood loss [92]. Bleeding complications did not occur at the time of insertion of the device in the presence of adequate hemostatic or replacement therapy.

In women with menorrhagia, often a combination of antifibrinolytic and hormonal therapy is used. Despite the fact that the combination of tranexamic acid and oral

Table 4 Antifibrinolytic agents for the treatment of von Willebrand disease

\begin{tabular}{|c|c|c|}
\hline Formulation & $\begin{array}{l}\text { Available } \\
\text { concentration }\end{array}$ & $\operatorname{Dose}^{\mathrm{a}}$ \\
\hline $\begin{array}{l}\text { Tranexamic acid } \\
\text { intravenous }\end{array}$ & $10 \mathrm{mg} / \mathrm{ml}$ & $\begin{array}{l}0.5-1 \mathrm{~g}, 2-3 \mathrm{x} \text { daily }(1 \mathrm{ml} / \mathrm{min}) \\
\text { Children } \geq 1 \text { year: } 20 \mathrm{mg} / \mathrm{kg} / \text { day in } 2-3 \text { doses a day }\end{array}$ \\
\hline Tranexamic acid oral & $\begin{array}{l}650 \mathrm{mg}(\mathrm{US}) \\
500 \mathrm{mg}(\mathrm{EU})\end{array}$ & $\begin{array}{l}0.5-1 \mathrm{~g} \text { in } 2-4 \text { doses a day } \\
\text { Children } \geq 1 \text { year: } 20 \mathrm{mg} / \mathrm{kg} / \mathrm{day} \text {, in } 2-3 \text { doses a day }\end{array}$ \\
\hline $\begin{array}{l}\text { Tranexamic acid } \\
\text { mouth rinse }\end{array}$ & $50 \mathrm{mg} / \mathrm{ml}$ & $\begin{array}{l}0.5-1.5 \mathrm{~g}(15-25 \mathrm{mg} / \mathrm{kg}) \text {, in } 2-3 \text { doses a day "swish and swallow or spit" } \\
\text { Children } \geq 1 \text { year: } 20 \mathrm{mg} / \mathrm{kg} / \text { day, in } 2-3 \text { doses a day }\end{array}$ \\
\hline $\begin{array}{l}\text { Aminocaproic acid } \\
\text { intravenous }\end{array}$ & $250 \mathrm{mg} / \mathrm{ml}$ & $\begin{array}{l}\text { Starting dose: } 4-5 \mathrm{~g} \text { slowly during the first hour, followed by continuous infusion of } 1 \mathrm{~g} / \mathrm{h} \\
\text { Children: } 100 \mathrm{mg} / \mathrm{kg} \text { or } 3 \mathrm{~g} / \mathrm{m}^{2} \text { slowly }(>1 \mathrm{~h} \text { ), followed by continuous infusion of } 33.3 \mathrm{mg} / \mathrm{kg} / \mathrm{h} \text { or } 1 \\
\mathrm{g} / \mathrm{m}^{2} / \mathrm{h}\end{array}$ \\
\hline $\begin{array}{l}\text { Aminocaproic acid } \\
\text { oral }\end{array}$ & $\begin{array}{l}500 \mathrm{mg} \text { and } \\
1000 \mathrm{mg}\end{array}$ & $\begin{array}{l}\text { Starting dose: } 4-5 \mathrm{~g} \text {, followed by } 1-1.25 \mathrm{~g} / \mathrm{h} \text { or } 4-6 \mathrm{~g} \text { every } 4-6 \mathrm{~h} \text {, with a max. dose of } 24 \mathrm{~g} / \mathrm{day} \\
\text { Children: starting } 100 \mathrm{mg} / \mathrm{kg} \text {, followed by } 3 \mathrm{~g} / \mathrm{m}^{2} \text { during the first hour, followed by } 33.3 \mathrm{mg} / \mathrm{kg} \text { or } 1 \\
\mathrm{~g} / \mathrm{m}^{2} \text { every hour. Max. dose: } 18 \mathrm{~g} / \mathrm{m}^{2} / \text { day or } 600 \mathrm{mg} / \mathrm{kg} / \text { day }\end{array}$ \\
\hline $\begin{array}{l}\text { Aminocaproic acid } \\
\text { mouth rinse }\end{array}$ & $250 \mathrm{mg} / \mathrm{ml}$ & $\begin{array}{l}\text { Starting dose: } 4-5 \mathrm{~g} \text {, followed by } 1-1.25 \mathrm{~g} / \mathrm{h} \text {, with a max. dose of } 24 \mathrm{~g} / \text { day "swish and swallow or } \\
\text { spit" } \\
\text { Children: starting } 100 \mathrm{mg} / \mathrm{kg} \text {, followed by } 3 \mathrm{~g} / \mathrm{m}^{2} \text { during the first hour, followed by } 33.3 \mathrm{mg} / \mathrm{kg} \text { or } 1 \\
\mathrm{~g} / \mathrm{m}^{2} \text { every hour. Max. dose: } 18 \mathrm{~g} / \mathrm{m}^{2} / \mathrm{day} \text { or } 600 \mathrm{mg} / \mathrm{kg} / \text { day }\end{array}$ \\
\hline
\end{tabular}

${ }^{\mathrm{a}}$ Data derived from [84] 


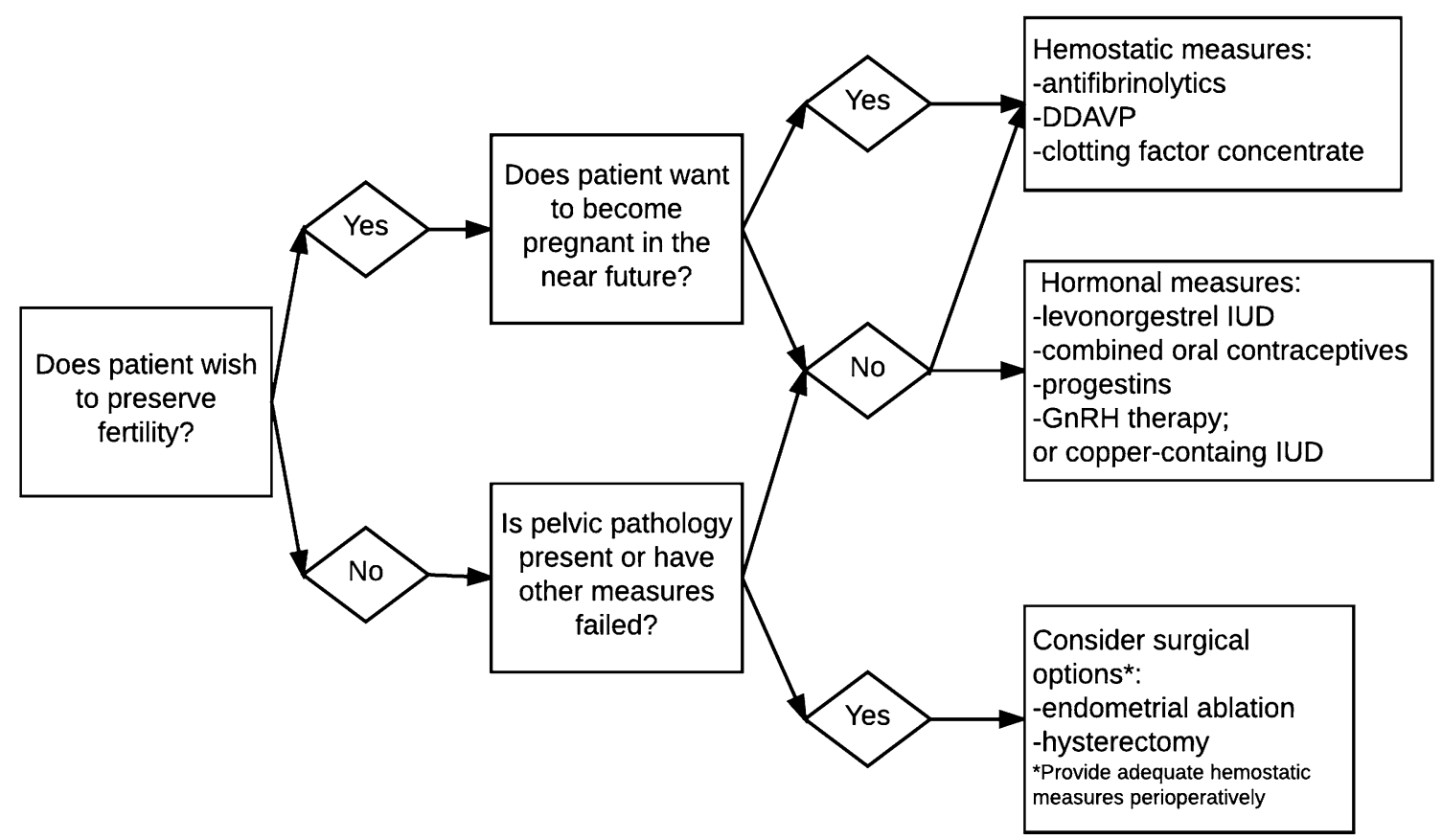

Fig. 2 Treatment of menorrhagia [94]

contraceptives may be pro-thrombotic, no reports of thromboembolic events in women with VWD using this combination of medication have been reported. Therefore, it is assumed that a combination of antifibrinolytic and hormonal therapy is safe [93]. For all treatment options in women with menorrhagia, see the treatment algorithm in Fig. 2 [94].

\subsubsection{Additional Measures}

In case of epistaxis, xylometazoline nose drops can be applied intranasally to induce vasoconstriction. When the active bleeding focus can be identified, chemical or electrical cauterization performed by an emergency- or ear, nose, and throat physician is the preferred method of treatment [95]. In addition, to prevent bleeding after surgical or dental procedures, secure suturing is important to achieve local hemostasis. Additional measures for wound sealing and promotion of wound healing include application of (autologous) fibrin glue or platelet-rich clots $[96,97]$.

\subsection{Management of Pregnancy and Delivery}

In case of pregnancy in a VWD patient, a hematologist should be consulted in the first trimester in order to coordinate treatment for pregnancy and delivery if necessary. In VWD type 1 and 2, VWF:Ag, VWF:RCo, and FVIII:C should be monitored at 12 weeks and 30-34 weeks. If VWF and FVIII levels are inadequate $(<0.50$
$\mathrm{U} / \mathrm{ml}$ ) at 30-34 weeks, a multidisciplinary team consisting of a hematologist, pediatric hematologist, gynecologist, and anesthesiologist with expertise in bleeding disorders should establish a treatment plan that includes timing and dosing of factor concentrate and/or antifibrinolytic agent administration during childbed and hospitalization as well as mode of (regional) anesthesia and indication for atraumatic delivery. In case of post-partum hemorrhage, factor concentrate should be administered, taking possible other obstetric causes of bleeding into account [98]. When good responsiveness to DDAVP has been demonstrated prior to the event, DDAVP can be administered after clamping of the umbilical cord. Because of the decrease of VWF and FVIII to pre-existent levels after delivery [99], it is recommended to supply tranexamic acid four times a day at $500-1000 \mathrm{mg}$ or aminocaproic acid 4-6 g every 4-6 h orally during the first 7 days post-partum.

Generally, in type 1 VWD, VWF and FVIII levels generally rise to relatively normal values in the third trimester and maternal problems are not expected during delivery. Historically, guidelines consistently have advised to aim for target levels of VWF and FVIII $>0.50 \mathrm{U} / \mathrm{ml}$ before delivery [1]. However, Szecsi et al. reported that in normal pregnancies FVIII:C at 38-42 weeks was $130-430 \%(n=73)$ [100]. This fact, combined with the observation that the risk of post-partum hemorrhage despite specialized care is greater in women with VWD, means it is likely that women may be "undertreated" currently at the time of delivery $[15,98]$. 
To determine the indication for an atraumatic delivery, invasive prenatal diagnostic procedures can be performed in weeks 33-34 of the pregnancy if the causative VWF gene mutation is known. If maternal FVIII and/or VWF is $<0.50 \mathrm{IU} / \mathrm{ml}$, treatment with factor concentrate is indicated during such procedures. When a child with (potentially) type 3 VWD or a clinically severe type 1 or 2 VWD is due to be born, an atraumatic delivery should be pursued. Vaginal delivery is usually preferred. Only in cases of severe emergency should a forceps delivery be performed (no vacuum extraction) and no vaginal breech delivery and no expulsion for $>1 \mathrm{~h}$ are to be allowed. A caesarean section should be performed without hesitation under adequate replacement therapy when complications are expected. Fetal scalp blood testing and placement of a fetal scalp electrode should be avoided. VWF and FVIII cord blood analysis to diagnose the newborn is only indicated in severe types 1 and 2 and in type 3 VWD. Due to relatively high VWF and FVIII levels directly after birth due to activation in cord blood, measurement of VWF and FVIII in milder cases should be repeated a few weeks after birth if results are dubious [101]. Intramuscular injections in the neonate should be avoided or replaced by subcutaneous injection as long as VWF and FVIII levels are unknown. In case of a (possible) severe VWD (VWF $<0.05 \mathrm{U} / \mathrm{ml}$ and/or FVIII $<0.05 \mathrm{U} / \mathrm{ml}$ ), observation of the neonate during the first $24 \mathrm{~h}$ is indicated. Routine ultrasound screening is not recommended in neonates with type 3 VWD, but should be performed consequently and rapidly when additional bleeding risks are present or clinical symptoms suggesting intracranial bleeding are observed. When ultrasound is not acutely available, replacement therapy should be given prior to imaging when symptoms are most suspect.

\subsection{Treatment of Angiodysplasia-Related Gastrointestinal Bleeding}

Gastrointestinal bleeding is a common and sometimes lifethreatening problem in VWD patients, with a prevalence of $11-27 \%$, depending on disease type [14]. In patients lacking high-molecular weight (HMW) VWF multimersas in VWD type 2A-angiodysplastic lesions are often found to be causative [102]. In vitro and in vivo studies have identified VWF as a regulator of angiogenesis through different pathways, although the exact mechanisms remain unclear [103]. Identification of angiodysplasia is often difficult. The diagnostic approach starts with endoscopy; however, in a substantial proportion of cases results are negative, especially when the lesions are small and not abundant. Additional methods include video capsule endoscopy, helical computed tomography and angiography. Often repetitive investigations are necessary to ultimately diagnose angiodysplasia [104]. Therefore, it is important to repeat diagnostic procedures in VWD patients presenting with unexplained iron-deficient anemia or clinical symptoms of gastrointestinal bleeding, especially in those lacking HMW VWF multimers.

In most patients with congenital VWD, replacement therapy with factor concentrates is sufficient, but often seems to be less effective than in other types of bleeding [102, 105]. Several other pharmacological therapies have been proposed for the often complex management of recurrent gastrointestinal bleeding due to angiodysplasia. A problem with these therapies is that effectiveness has only been described in small case series and case reports, with variable results. It is also likely that there is a significant publication bias, as reports of successful pharmacologic treatment are more likely to be published than unsuccessful ones. As a consequence, these drugs have not yet been approved for treatment of angiodysplasia and are currently only prescribed off-label. Therefore, further studies on potentially effective pharmacologic agents are required.

\subsubsection{Octreotide}

Treatment with octreotide, a somatostatin analogue, has shown high efficacy and safety in studies involving non-VWD patients with chronic bleeding due to angiodysplasia. Regretfully, these studies included relatively small numbers of patients and differed greatly in drug dosage and route and duration of administration of the drug. Also, follow-up time was relatively short [106]. In the literature, three cases of VWD patients treated with octreotide have been described. A case series of two VWD patients with massive and prolonged gastrointestinal bleeding resistant to conventional treatment was described by Bowers [107]. A rise in baseline VWF:Act and hemoglobin was observed after initial intravenous administration and continued subcutaneous administration of octreotide and no hospital admissions were required during follow-up. In 2005, Krikis et al. reported on a case of a VWD patient with recurrent and life-threatening gastrointestinal bleeding. This patient was treated with octreotide long-acting release (LAR) $20 \mathrm{mg}$ by intramuscular injection once a month and propranolol $20 \mathrm{mg}$ three times a day. During follow-up, the patient experienced no bleeding. Laboratory evaluations, however, showed no rise in VWF levels [108].

\subsubsection{Thalidomide}

Thalidomide inhibits angiogenesis by suppression of vascular endothelial growth factor (VEGF) [109], making it an interesting drug candidate for the treatment of angiodysplasia. In a literature review, Engelen et al. described 19 relevant publications on thalidomide use in angiodysplasiarelated gastrointestinal bleeding [110]. These articles included one randomized controlled trial, two prospective 
cohort studies, seven case series, and 14 case reports. A total of 115 patients receiving thalidomide were described. Dosing ranged from 50 to $400 \mathrm{mg} /$ day, with an average dose of $100 \mathrm{mg} /$ day. In all studies, a beneficial effect of thalidomide was shown as in only two of the cases thalidomide treatment had no effect on gastrointestinal bleeding. Four out of the total reported patients had congenital VWD. In all VWD patients, treatment with thalidomide was successful and bleeding episodes stopped. In one patient this effect was temporary and the dose needed to be increased. In 17 out of the total of 115 patients, thalidomide was withdrawn due to side effects. Although the results of thalidomide therapy are promising, severe side effects such as neurotoxicity and concerns about possible oncogenetic properties limit the use of thalidomide as long-term therapy.

\subsubsection{Lenalidomide}

Lenalidomide is a thalidomide analog that also has an antiangiogenic effect, but with a somewhat more favorable adverse effects pattern. A retrospective chart review of five VWD patients with angiodysplasia receiving lenalidomide was performed in 2013 by Kohli et al. [111]. Patients received a starting dose of $5 \mathrm{mg}$ daily. In one patient, it was necessary to increase the dosage up to $15 \mathrm{mg}$ daily due to recurrent gastrointestinal bleeding. Mean bleed-free duration was 1 year and the number of endoscopies was significantly lower after treatment. Fatigue was the most commonly reported side effect and one patient even discontinued treatment due to excessive fatigue.

\subsubsection{Statins}

Statins in high doses have been reported to inhibit angiogenesis [112]. In 2008, Sohal and Laffan reported a severe type 1 VWD patient with refractory bleeding due to angiodysplasia in the gastrointestinal tract [113]. Atorvastatin was administered at $10 \mathrm{mg}$ daily, with dose escalation to $40 \mathrm{mg} /$ day over the following 3 months. During 6 months of follow-up, bleeding gradually subsided and no side effects were reported. Following this report, Alikhan and Keeling reported on a type 2A VWD patient in whom $10 \mathrm{mg}$ atorvastatin was commenced daily, increasing the dose to $40 \mathrm{mg}$ daily over 4 months [114]. A reduction in blood transfusions was observed. After a dose increase to $80 \mathrm{mg}$, the patient had not needed any blood transfusions or hospitalization over a follow-up period of 9 months. No side effects were reported.

\subsubsection{Hormonal and Antihormonal Therapy}

Estrogen and progesterone have been investigated in a number of studies in non-VWD angiodysplasia patients.
This mode of therapy has shown no beneficial effect and is no longer recommended in gastrointestinal angiodysplasia [115]. In recent years, tamoxifen has been identified as an effective therapy for the management of patients with hereditary hemorrhagic telangiectasia having recurrent bleeds [116]. The counterintuitive benefits of an antiestrogen for treating telangiectasia were noted by chance. It is hypothesized that when estrogen binds to its receptors, it induces proliferation of the blood vessels, and thus telangiectatic lesions [117]. A case report by Thachil on two VWD patients with angiodysplasia was published in 2013. In one patient, an immediate reduction of bleeding episodes was observed, and bleeding stopped completely after 3 months of tamoxifen treatment and persisted during the 14-month follow-up period. The other patient discontinued treatment after 4 months due to vaginal discharge. Six months after cessation of treatment in this patient, no further bleeds had occurred and no angiodysplastic lesions were observed during endoscopy.

\subsubsection{Danazol}

Danazol has been shown to increase FVIII levels and reduce bleeding frequency in hemophilia A patients [118]. Other studies, however, could not reproduce these findings [119]. Therefore, the effect is thought to likely be more at the endothelial level, rather than the result of increased coagulation factor levels. The only study of danazol in angiodysplasia has been performed by Botero et al. [120]. Three VWD patients with refractory gastrointestinal bleeding were reported who were receiving danazol 100-500 mg daily. One patient experienced two transfusion-free periods of 6 months almost directly after starting danazol. The other patients needed 6 months -3 years to achieve transfusion independence. In all patients, concomitant endoscopic management was still required. In one patient, danazol had to be discontinued due to drug-induced liver toxicity.

\subsection{Prophylactic Prevention of Bleeding}

Severely affected VWD patients who suffer from recurrent bleeding episodes may be treated with VWF concentrates two or three times a week in order to prevent bleeding (prophylaxis). Several retrospective case series of VWD patients on prophylaxis reported beneficial results [121, 122]. So far only one prospective dose-escalating study has been performed to evaluate the use of prophylaxis in type 1, 2, and 3 VWD patients with a severe bleeding phenotype. A major reduction of the number of bleedings, such as recurrent gastrointestinal bleeding and joint bleeding or severe epistaxis was shown. Nearly all patients required $50 \mathrm{VWF}: \mathrm{RCo} \mathrm{IU} / \mathrm{kg}$ two or three times a 
week. This study shows that bleeding may be reduced in patients by regular VWF concentrate administration, although the study was limited by slow and limited inclusion of patients (total number included 12) [123]. In a related comment on the article by Abshire et al., Federici proposed that patients with severe VWD, irrespective of type of VWD, who suffer from recurrent bleedings may benefit from prophylaxis, and this option must be discussed and offered to patients with a severe bleeding phenotype [124].

\section{Emerging Therapies in VWD}

Treatment for VWD has not evolved much over the last decades. For years, the only option for VWD patients unresponsive to desmopressin was treatment with plasmaderived factor concentrates. These products are effective in the prevention and treatment of bleeding in VWD, but adverse events such as allergic reactions and thrombosis have been reported $[57,125]$. In addition, possible transmission of viral or prion diseases remains a concern in products derived from donor plasma, although this has not occurred for a long time due to deployment of viral inactivation technologies. Meanwhile in hemophilia, treatment with recombinant factor concentrates has already been an established therapy for many years, and treatment with extended half-life products are a promising solution for current prophylaxis limitations. Here we discuss possible future options for better and more personalized treatment in VWD.

\subsection{Individualized Management Based on Population Pharmacokinetic Modeling}

Currently, VWF/FVIII concentrate is dosed according to body weight, type, and location of bleeding while aiming for certain VWF and FVIII target levels. Postoperatively, dosing is based on these parameters, but also on a crude approximation of clearance of VWF/FVIII concentrate in case of continuous dosing or crude half-life estimations in case of bolus infusions.

DDAVP is administered in a standardized dose of 0.3 $\mu \mathrm{g} / \mathrm{kg}$ intravenously every 12-24 $\mathrm{h}$. When administered sequentially in short intervals, tachyphylaxis occurs due to depletion of the VWF storage in the endothelium.

In both of the above-mentioned treatment strategies, other individual patient characteristics, such as age, lean body mass, liver and kidney function, and baseline VWF and FVIII plasma levels are not taken into account. Furthermore, scarce data is available on the pharmacokinetics (PK) of VWF/FVIII concentrate during surgery and no population PK-models have been constructed [126, 127].
Moreover, in patients with a partial deficiency of VWF and FVIII, the rise of these clotting factors during stress due to interactions with the vascular endothelium remains to be elucidated. A population PK model based on both DDAVP and factor concentrate administration may prove valuable in bleeding disorders such as VWD, as it has been for dosing regimens in hemophilia A [128]. By taking individual clearance differences into account as well as modelling the interaction with the vascular endothelium in the different VWD types, treatment can be more tailored to the individual requirements of the patient.

\subsection{Interleukin-11}

Early studies in wild type mice and VWD mouse models showed that interleukin-11 (IL-11) significantly increases plasma VWF. Mice treated with subcutaneous IL-11 for 7 consecutive days had a twofold increase of FVIII and VWF. In 2008, Ragni et al. reported a phase II prospective trial in nine patients with mild VWD using different dosages of rIL-11 given subcutaneously for 7 days. This resulted in a 1.5- to threefold increase over baseline. Because platelet mRNA expression increased, they suggested that the mechanism of effect of rIL-11 was the upregulation of VWF mRNA [129]. In additional clinical studies the same group showed that menstrual bleeding severity could be reduced by rIL-11 in patients with mild VWD and refractory menorrhagia [130]. More recently it was also shown that in patients with mild or moderate VWD, who were unresponsive to DDAVP, rIL-11 increased FVIII and VWF nearly twofold [131].

\subsection{Aptamers}

Aptamers are a new class of oligonucleotide-based drugs that are able to block various proteins. ARC1779 is an aptamer that binds to the A1 domain of VWF, thereby blocking the interaction with platelet GpIb. Animal studies have shown that this aptamer blocks thrombus formation. In humans this aptamer was studied in patients with type 2B VWD. This type of VWD is characterized by increased binding of the A1 domain to the GpIb receptor on platelets. In patients treated with DDAVP, the rise of VWF in plasma is accompanied by thrombocytopenia, due to platelet aggregation. The aptamer ARC1779 was able to reduce the platelet drop after DDAVP treatment, and increased VWF:Ag and VWF:RCo [132, 133]. Therefore it is suggested that the aptamer can be used as an antibleeding drug in VWD patients [134]. Another potential application can be the use of the aptamer in VWD type $2 \mathrm{~B}$ patients with hepatitis $\mathrm{C}$ and thrombocytopenia. The aptamer may be able to raise platelet counts, making these patients eligible for interferon therapy [133]. Blockade of VWF by a longer 
acting aptamer with subcutaneous bioavailability such as ARC15105 could potentially be useful [133]. However, no clinical trials have been performed to determine efficacy.

\subsection{Gene Therapy}

In recent years several advances have been reported using gene therapy in congenital bleeding disorders, especially in hemophilia B. Severely affected hemophilia B patients (FIX $<1 \%$ ) treated with adeno-associated virus 8 (AAV8)mediated gene transfer with a codon-optimized wild type FIX gene showed FIX levels up to $5-8 \%$ of normal and reported a strong reduction in bleeding and exogenous FIX concentrate use $[135,136]$.

Gene therapy in VWD is challenging due to the large size of the VWF gene, leading to difficulties in inserting VWF cDNA in most viral gene transfer vectors. For VWD, preliminary gene therapy mice studies have been reported. De Meyer et al. used a mouse model to study liver-specific gene transfer of murine VWF expressing vector by hydrodynamic injection. They showed a temporary expression of VWF by the liver, resulting in VWF levels and consequent restoration of in vivo platelet adhesion and aggregation [137]. Furthermore, Wang et al. showed in a mouse model that lentiviral vectors could transfer intact murine VWF cDNA in vivo directly to the neonatal liver of VWF knockout mice. This resulted in production of VWF multimers and a partial correction of VWF levels in 33\% of the treated mice [138]. Although these results seem promising, further improvements in efficiency are needed before clinical application is within reach.

\section{Conclusion}

Over the last decades, treatment of VWD has mainly been based on DDAVP and plasma-derived factor concentrates. With the US Food and Drug Administration approval of the first recombinant VWF concentrate for treatment of bleeding in VWD patients in 2015, treatment options for VWD are now finally being expanded. As research on pathophysiology of VWD and on new treatment modalities is ongoing, it is likely that in the upcoming years the options to tailor treatment to individual patient needs will improve.

\section{Compliance with Ethical Standards}

Funding No funding was received for the preparation or publication of this manuscript.

Conflict of interest JMH has no conflicts of interest. MHC has received unrestricted research grants for investigator-initiated studies on the treatment of von Willebrand disease from CSL Behring and the
Dutch "Innovatiefonds," and has received travel funding for hematological conferences, not specifically for the subject of this manuscript, according to guidelines from the following companies: Pfizer, Shire, Bayer, Novo Nordisk, Novartis, and CSL Behring. FWGL has received unrestricted research grants from CSL Behring and Shire, and is a consultant for UniQure, Novo Nordisk, and Shire.

Open Access This article is distributed under the terms of the Creative Commons Attribution-NonCommercial 4.0 International License (http://creativecommons.org/licenses/by-nc/4.0/), which permits any noncommercial use, distribution, and reproduction in any medium, provided you give appropriate credit to the original author(s) and the source, provide a link to the Creative Commons license, and indicate if changes were made.

\section{References}

1. Nichols WL, Hultin MB, James AH, Manco-Johnson MJ, Montgomery RR, Ortel TL, et al. von Willebrand disease (VWD): evidence-based diagnosis and management guidelines, the National Heart, Lung, and Blood Institute (NHLBI) Expert Panel report (USA). Haemophilia. 2008;14(2):171-232.

2. Rodeghiero F, Castaman G, Dini E. Epidemiological investigation of the prevalence of von Willebrand's disease. Blood. 1987;69(2):454-9.

3. Huizinga EG, Tsuji S, Romijn RA, Schiphorst ME, de Groot PG, Sixma JJ, et al. Structures of glycoprotein Ibalpha and its complex with von Willebrand factor A1 domain. Science. 2002;297(5584):1176-9.

4. Sixma JJ, Wester J. The hemostatic plug. Semin Hematol. 1977;14(3):265-99.

5. Leebeek FW, Eikenboom JC. Von Willebrand's disease. N Engl J Med. 2016;375(21):2067-80.

6. Wagner DD. Cell biology of von Willebrand factor. Annu Rev Cell Biol. 1990;6:217-46.

7. Kaufmann JE, Vischer UM. Cellular mechanisms of the hemostatic effects of desmopressin (DDAVP). J Thromb Haemost. 2003;1(4):682-9.

8. Dong JF, Moake JL, Nolasco L, Bernardo A, Arceneaux W, Shrimpton CN, et al. ADAMTS-13 rapidly cleaves newly secreted ultralarge von Willebrand factor multimers on the endothelial surface under flowing conditions. Blood. 2002;100(12):4033-9.

9. Sadler JE, Budde U, Eikenboom JC, Favaloro EJ, Hill FG, Holmberg L, et al. Update on the pathophysiology and classification of von Willebrand disease: a report of the Subcommittee on von Willebrand Factor. J Thromb Haemost. 2006;4(10):2103-14.

10. Schooten CJ, Tjernberg P, Westein E, Terraube V, Castaman G, Mourik JA, et al. Cysteine-mutations in von Willebrand factor associated with increased clearance. J Thromb Haemost. 2005;3(10):2228-37.

11. Boender J, Kruip MJ, Leebeek FW. A diagnostic approach to mild bleeding disorders. J Thromb Haemost. 2016;14(8):1507-16.

12. Rodeghiero F, Tosetto A, Abshire T, Arnold DM, Coller B, James P, et al. ISTH/SSC bleeding assessment tool: a standardized questionnaire and a proposal for a new bleeding score for inherited bleeding disorders. $\mathrm{J}$ Thromb Haemost. 2010;8(9):2063-5.

13. Elbatarny M, Mollah S, Grabell J, Bae S, Deforest M, Tuttle A, et al. Normal range of bleeding scores for the ISTH-BAT: adult and pediatric data from the merging project. Haemophilia. 2014;20(6):831-5. 
14. De Wee EM, Leebeek FWG, Eikenboom JCJ. Diagnosis and management of von Willebrand Disease in the Netherlands. Semin Thromb Hemost. 2011;37(5):480-7.

15. Stoof SCM, van Steenbergen HW, Zwagemaker A, Sanders YV, Cannegieter SC, Duvekot JJ, et al. Primary postpartum haemorrhage in women with von Willebrand disease or carriership of haemophilia despite specialised care: a retrospective survey. Haemophilia. 2015;21(4):505-12.

16. van Galen KPM, Sanders YV, Vojinovic U, Eikenboom J, Cnossen MH, Schutgens REG, et al. Joint bleeds in von Willebrand disease patients have significant impact on quality of life and joint integrity: a cross-sectional study. Haemophilia. 2015;21(3):e185-92.

17. Veyradier A, Boisseau P, Fressinaud E, Caron C, Ternisien C, Giraud M, et al. A laboratory phenotype/genotype correlation of 1167 French patients from 670 families with von Willebrand disease: a new epidemiologic picture. Medicine. 2016;95(11):e3038.

18. Hampshire DJ, Goodeve AC. The international society on thrombosis and haematosis von Willebrand disease database: an update. Semin Thromb Hemost. 2011;37(5):470-9.

19. Bowman M, Tuttle A, Notley C, Brown C, Tinlin S, Deforest M, et al. The genetics of Canadian type 3 von Willebrand disease: further evidence for co-dominant inheritance of mutant alleles. J Thromb Haemost. 2013;11(3):512-20.

20. Goodeve A, Eikenboom J, Castaman G, Rodeghiero F, Federici $\mathrm{AB}$, Batlle $\mathrm{J}$, et al. Phenotype and genotype of a cohort of families historically diagnosed with type 1 von Willebrand disease in the European study, Molecular and Clinical Markers for the Diagnosis and Management of Type 1 von Willebrand Disease (MCMDM-1VWD). Blood. 2007;109(1):112-21.

21. James PD, Notley C, Hegadorn C, Leggo J, Tuttle A, Tinlin S, et al. The mutational spectrum of type 1 von Willebrand disease: Results from a Canadian cohort study. Blood. 2007;109(1):145-54.

22. Goodeve AC. The genetic basis of von Willebrand disease. Blood Rev. 2010;24(3):123-34.

23. Castaman G, Tosetto A, Eikenboom JC, Rodeghiero F. Blood group significantly influences von Willebrand factor increase and half-life after desmopressin in von Willebrand disease Vicenza. J Thromb Haemost. 2010;8(9):2078-80.

24. Gallinaro L, Cattini MG, Sztukowska M, Padrini R, Sartorello F, Pontara E, et al. A shorter von Willebrand factor survival in $\mathrm{O}$ blood group subjects explains how $\mathrm{ABO}$ determinants influence plasma von Willebrand factor. Blood. 2008;111(7):3540-5.

25. Rydz N, Swystun LL, Notley C, Paterson AD, Riches JJ, Sponagle $\mathrm{K}$, et al. The C-type lectin receptor CLEC4M binds, internalizes, and clears von Willebrand factor and contributes to the variation in plasma von Willebrand factor levels. Blood. 2013;121(26):5228-37.

26. Rastegarlari G, Pegon JN, Casari C, Odouard S, Navarrete AM, Saint-Lu N, et al. Macrophage LRP1 contributes to the clearance of von Willebrand factor. Blood. 2012;119(9):2126-34.

27. Smith NL, Chen MH, Dehghan A, Strachan DP, Basu S, Soranzo N, et al. Novel associations of multiple genetic loci with plasma levels of factor VII, factor VIII, and von Willebrand factor: The CHARGE (Cohorts for Heart and Aging Research in Genome Epidemiology) Consortium. Circulation. 2010;121(12):1382-92.

28. van Loon J, Dehghan A, Weihong T, Trompet S, McArdle WL, Asselbergs FF, et al. Genome-wide association studies identify genetic loci for low von Willebrand factor levels. Eur J Hum Genet. 2016;24(7):1035-40.

29. Desch KC, Ozel AB, Siemieniak D, Kalish Y, Shavit JA, Thornburg CD, et al. Linkage analysis identifies a locus for plasma von Willebrand factor undetected by genome-wide association. Proc Natl Acad Sci USA. 2013;110(2):588-93.

30. van Loon JE, Sonneveld MA, Praet SF, de Maat MP, Leebeek FW. Performance related factors are the main determinants of the von Willebrand factor response to exhaustive physical exercise. PLoS One. 2014;9(3):e91687.

31. Danesh J, Wheeler JG, Hirschfield GM, Eda S, Eiriksdottir G, Rumley A, et al. C-reactive protein and other circulating markers of inflammation in the prediction of coronary heart disease. N Engl J Med. 2004;350(14):1387-97.

32. Blann AD, Naqvi T, Waite M, McCollum CN. von Willebrand factor and endothelial damage in essential hypertension. J Hum Hypertens. 1993;7(2):107-11.

33. Knol HM, Kemperman RF, Kluin-Nelemans HC, Mulder AB, Meijer K. Haemostatic variables during normal menstrual cycle. A systematic review. Thromb Haemost. 2012;107(1):22-9.

34. Sanders YV, Giezenaar MA, Laros-van Gorkom BAP, Meijer K, van der Bom JG, Cnossen $\mathrm{MH}$, et al. Von Willebrand disease and aging: an evolving phenotype. J Thromb Haemost. 2014;12(7):1066-75.

35. Vischer UM, Herrmann FR, Peyrard T, Nzietchueng R, Benetos A. Plasma von Willebrand factor and arterial aging. J Thromb Haemost. 2005;3(4):794-5.

36. Siew DA, Mangel J, Laudenbach L, Schembri S, Minuk L. Desmopressin responsiveness at a capped dose of $15 \mu \mathrm{g}$ in type 1 von Willebrand disease and mild hemophilia A. Blood Coagul Fibrinolysis. 2014;25(8):820-3.

37. Seary ME, Feldman D, Carcao MD. DDAVP responsiveness in children with mild or moderate haemophilia A correlates with age, endogenous FVIII: $\mathrm{C}$ level and with haemophilic genotype. Haemophilia. 2012;18(1):50-5.

38. Fjellestad-Paulsen A, Hoglund P, Lundin S, Paulsen O. Pharmacokinetics of 1-deamino-8-D-arginine vasopressin after various routes of administration in healthy volunteers. Clin Endocrinol (Oxf). 1993;38(2):177-82.

39. Castaman G, Lethagen S, Federici AB, Tosetto A, Goodeve A, Budde $\mathrm{U}$, et al. Response to desmopressin is influenced by the genotype and phenotype in type 1 von Willebrand disease (VWD): results from the European Study MCMDM-1VWD. Blood. 2008;111(7):3531-9.

40. Rodeghiero F, Castaman G, Di Bona E, Ruggeri M. Consistency of responses to repeated DDAVP infusion in patients with von Willebrand's disease and hemophilia A. Blood. 1989;74(6):1997-2000.

41. Mannucci PM, Bettega D, Cattaneo M. Patterns of development of tachyphylaxis in patients with haemophilia and von Willebrand disease after repeated doses of desmopressin (DDAVP). Br J Haematol. 1992;82(1):87-93.

42. Revel-Vilk S, Schmugge M, Carcao MD, Blanchette P, Rand ML, Blanchette VS. Desmopressin (DDAVP) responsiveness in children with von Willebrand disease. J Pediatr Hematol Oncol. 2003;25(11):874-9.

43. Federici AB, Mazurier C, Berntorp E, Lee CA, Scharrer I, Goudemand $\mathrm{J}$, et al. Biologic response to desmopressin in patients with severe type 1 and type 2 von Willebrand disease: results of a multicenter European study. Blood. 2004;103(6):2032-8.

44. Castaman G, Tosetto A, Federici AB, Rodeghiero F. Bleeding tendency and efficacy of anti-haemorrhagic treatments in patients with type 1 von willebrand disease and increased von Willebrand factor clearance. Thromb Haemost. 2011;105(4):647-54.

45. Casonato A, Sartori MT, De Marco L, Girolami A. 1-Desamino8-D-arginine vasopressin (DDAVP) infusion in type IIB von Willebrand's disease: Shortening of bleeding time and induction 
of a variable pseudothrombocytopenia. Thromb Haemost. 1990;64(1):117-20.

46. Stoof SCM, Cnossen MH, de Maat MPM, Leebeek FWG, Kruip MJHA. Side effects of desmopressin in patients with bleeding disorders. Haemophilia. 2016;22(1):39-45.

47. Windyga J, Dolan G, Altisent C, Katsarou O, López Fernández MF, Zülfikar B. Practical aspects of factor concentrate use in patients with von Willebrand disease undergoing invasive procedures: a European survey. Haemophilia. 2016;22(5):739-51.

48. Karanth L, Barua A, Kanagasabai S, Nair NS. Desmopressin acetate (DDAVP) for preventing and treating acute bleeds during pregnancy in women with congenital bleeding disorders. Cochrane Database Syst Rev. 2015;9:CD009824.

49. Federici AB. The safety of plasma-derived von Willebrand/factor VIII concentrates in the management of inherited von Willebrand disease. Expert Opin Drug Saf. 2009;8(2):203-10.

50. Mannucci PM, Franchini M. The use of plasma-derived concentrates. In: Federici AB, Lee CA, Berntorp EE, Lillicrap D, Montgomery RR, editors. Von Willebrand disease. Oxford: Wiley-Blackwell; 2011. p. 200-6.

51. Favaloro EJ. Towards personalised therapy for von Willebrand disease: a future role for recombinant products. Blood Transfusion. 2016;14(3):262-76.

52. Laffan MA, Lester W, O'Donnell JS, Will A, Tait RC, Goodeve A, et al. The diagnosis and management of von Willebrand disease: a United Kingdom Haemophilia Centre Doctors Organization guideline approved by the British Committee for Standards in Haematology. $\mathrm{Br} \mathrm{J}$ Haematol. 2014;167(4):453-65.

53. Lubetsky A, Schulman S, Varon D, Martinowitz U, Kenet G, Gitel S, et al. Safety and efficacy of continuous infusion of a combined factor VIII-von Willebrand factor (vWF) concentrate (Haemate-P(TM)) in patients with von Willebrand disease. Thromb Haemost. 1999;81(2):229-33.

54. Mannucci PM, Chediak J, Hanna W, Byrnes J, Ledford M, Ewenstein BM, et al. Treatment of von Willebrand disease with a high-purity factor VIII/von Willebrand factor concentrate: a prospective, multicenter study. Blood. 2002;99(2):450-6.

55. Franchini M. Surgical prophylaxis in von Willebrand's disease: a difficult balance to manage. Blood Transfusion. 2008;6(Suppl. 2):s33-8.

56. Makris M, Colvin B, Gupta V, Shields ML, Smith MP. Venous thrombosis following the use of intermediate purity FVIII concentrate to treat patients with von Willebrand's disease. Thromb Haemost. 2002;88(3):387-8.

57. Coppola A, Franchini M, Makris M, Santagostino E, Di Minno G, Mannucci PM. Thrombotic adverse events to coagulation factor concentrates for treatment of patients with haemophilia and von Willebrand disease: a systematic review of prospective studies. Haemophilia. 2012;18(3):e173-87.

58. Di Paola J, Lethagen S, Gill J, Mannucci P, Manco-Johnson M, Bernstein J, et al. Presurgical pharmacokinetic analysis of a von Willebrand factor/factor VIII (VWF/FVIII) concentrate in patients with von Willebrand's disease (VWD) has limited value in dosing for surgery. Haemophilia. 2011;17(5):752-8.

59. Mannucci PO, Franchini M, Castaman G, Federici AB. Evidence-based recommendations on the treatment of von Willebrand disease in Italy. Blood Transfusion. 2009;7(2):117-26.

60. Mannucci PM. Treatment of von Willebrand's disease. New Engl J Med. 2004;351(7):683-94+730.

61. Windyga J, von Depka-Prondzinski M. Efficacy and safety of a new generation von Willebrand factor/factor VIII concentrate $\left(\right.$ Wilate ${ }^{\circledR}$ ) in the management of perioperative haemostasis in von Willebrand disease patients undergoing surgery. Thromb Haemost. 2011;105(6):1072-9.
62. Federici AB. The safety of plasma-derived von Willebrand/factor VIII concentrates in the management of inherited von Willebrand disease. Expert Opin Drug Saf. 2009;8(2):203-10.

63. Castaman G. Treatment of von Willebrand disease with FVIII/ VWF concentrates. Blood Transfusion. 2011;9(Suppl. 2):s9-13.

64. Schramm W. Haemate ${ }^{\circledR}$ P von Willebrand factor/factor VIII concentrate: 25 years of clinical experience. Haemophilia. 2008;14(SUPPL. 5):3-10.

65. Goudemand J, Scharrer I, Berntorp E, Lee CA, Borel-Derlon A, Stieltjes N, et al. Pharmacokinetic studies on Wilfactin ${ }^{\circledR}$, a von Willebrand factor concentrate with a low factor VIII content treated with three virus-inactivation/removal methods. J Thromb Haemost. 2005;3(10):2219-27.

66. Iorio A, Oliovecchio E, Morfini M, Mannucci PM. Italian registry of haemophilia and allied disorders. Objectives, methodology and data analysis. Haemophilia. 2008;14(3):444-53.

67. Mannucci PM, Federici AB. Antibodies to von Willebrand factor in von Willebrand disease. Adv Exp Med Biol. 1995;386:87-91.

68. Shelton-Inloes BB, Chehab FF, Mannucci PM, Federici AB, Sadler JE. Gene deletions correlate with the development of alloantibodies in von Willebrand disease. J Clin Invest. 1987;79(5):1459-65.

69. Ruggeri ZM, Ciavarella N, Mannucci PM, Molinari A, Dammacco F, Lavergne JM, et al. Familial incidence of precipitating antibodies in von Willebrand's disease: a study of four cases. J Lab Clin Med. 1979;94(1):60-75.

70. Baaij M, Van Galen KPM, Urbanus RT, Nigten J, Eikenboom JHC, Schutgens REG. First report of inhibitory von Willebrand factor alloantibodies in type $2 \mathrm{~B}$ von Willebrand disease. Br J Haematol. 2015;171(3):424-7.

71. Bergamaschini L, Mannucci PM, Federici AB, Coppola R, Guzzoni S, Agostoni A. Posttransfusion anaphylactic reactions in a patient with severe von Willebrand disease: role of complement and alloantibodies to von Willebrand factor. J Lab Clin Med. 1995;125(3):348-55.

72. Mannucci PM, Ruggeri ZM, Ciavarella N. Precipitating antibodies to factor VIII/von Willebrand factor in von Willebrand's disease: effects on replacement therapy. Blood. 1981;57(1):25-31.

73. Ciavarella N, Schiavoni M, Valenzano E. Use of recombinant factor VIla (NovoSeven ${ }^{\circledR}$ ) in the treatment of two patients with Type III von Willebrand's Disease and an inhibitor against von Willebrand Factor. Haemostasis. 1996;26:150-4.

74. Grossmann RE, Geisen U, Schwender S, Keller F. Continuous infusion of recombinant factor VIIa (NovoSeven ${ }^{\circledR}$ ) in the treatment of a patient with type III von Willebrand's disease and alloantibodies against von Willebrand factor. Thromb Haemost. 2000;83(4):633-4.

75. Astermark J, Donfield SM, DiMichele DM, Gringeri A, Gilbert SA, Waters $J$, et al. A randomized comparison of bypassing agents in hemophilia complicated by an inhibitor: the FEIBA NovoSeven Comparative (FENOC) Study. Blood. 2007;109(2):546-51.

76. Krause M, Königs C, Pillitteri D, Scholz T, Pilgrimm A, Kirchmaier C, et al. On-demand therapy after ITT failure in patient with von Willebrand disease type 3 and alloantibodies. Haemophilia. 2012;18:197.

77. Turecek PL, Mitterer A, Matthiessen HP, Gritsch H, Varadi K, Siekmann J, et al. Development of a plasma- and albumin-free recombinant von Willebrand factor. Hamostaseologie. 2009;29(Suppl 1):S32-8.

78. Mannucci PM, Kempton C, Millar C, Romond E, Shapiro A, Birschmann I, et al. Pharmacokinetics and safety of a novel recombinant human von Willebrand factor manufactured with a 
plasma-free method: a prospective clinical trial. Blood. 2013;122(5):648-57.

79. Gill JC, Castaman G, Windyga J, Kouides P, Ragni M, Leebeek FWG, et al. Hemostatic efficacy, safety, and pharmacokinetics of a recombinant von Willebrand factor in severe von Willebrand disease. Blood. 2015;126(17):2038-46.

80. Sindet-Pedersen S. Haemostasis in oral surgery-the possible pathogenetic implications of oral fibrinolysis on bleeding. Experimental and clinical studies of the haemostatic balance in the oral cavity, with particular reference to patients with acquired and congenital defects of the coagulation system Review. Dan Med Bull. 1991;38(6):427-43.

81. Katsaros D, Petricevic M, Snow NJ, Woodhall DD, Van Bergen R. Tranexamic acid reduces postbypass blood use: a doubleblinded, prospective, randomized study of 210 patients. Ann Thorac Surg. 1996;61(4):1131-5.

82. Later AF, Maas JJ, Engbers FH, Versteegh MI, Bruggemans EF, Dion RA, et al. Tranexamic acid and aprotinin in low- and intermediate-risk cardiac surgery: a non-sponsored, doubleblind, randomised, placebo-controlled trial. Eur J Cardiothorac Surg. 2009;36(2):322-9.

83. Gandhi R, Evans HM, Mahomed SR, Mahomed NN. Tranexamic acid and the reduction of blood loss in total knee and hip arthroplasty: a meta-analysis. BMC Res Notes. 2013;07(6):184.

84. van Galen KP, Engelen ET, Mauser-Bunschoten EP, van Es RJ, Schutgens RE. Antifibrinolytic therapy for preventing oral bleeding in patients with haemophilia or Von Willebrand disease undergoing minor oral surgery or dental extractions. Cochrane Database Syst Rev. 2015;12:CD011385.

85. Fernandez Lucas M, Liano F, Navarro JF, Sastre JL, Quereda C, Ortuno J. Acute renal failure secondary to antifibrinolytic therapy. Nephron. 1995;69(4):478-9.

86. Koo JR, Lee YK, Kim YS, Cho WY, Kim HK, Won NH. Acute renal cortical necrosis caused by an antifibrinolytic drug (tranexamic acid). Nephrol Dial Transplant. 1999;14(3):750-2.

87. de Wee EM, Knol HM, Mauser-Bunschoten EP, van der Bom JG, Eikenboom JCJ, Fijnvandraat K, et al. Gynaecological and obstetric bleeding in moderate and severe von willebrand disease. Thromb Haemost. 2011;106(5):885-92.

88. Ragni MV, Machin N, Malec LM, James AH, Kessler CM, Konkle BA, et al. Von Willebrand factor for menorrhagia: a survey and literature review. Haemophilia. 2016;22(3):397-402.

89. Kouides PA, Phatak PD, Burkart P, Braggins C, Cox C, Bernstein $\mathrm{Z}$, et al. Gynaecological and obstetrical morbidity in women with type I von Willebrand disease: results of a patient survey. Haemophilia. 2000;6(6):643-8.

90. Kwiecien M, Edelman A, Nichols MD, Jensen JT. Bleeding patterns and patient acceptability of standard or continuous dosing regimens of a low-dose oral contraceptive: a randomized trial. Contraception. 2003;67(1):9-13.

91. Zhu PD, Luo HZ, Shi WL, Wang JD, Cheng J, Xu RH, et al. Observation of the activity of factor VIII in the endometrium of women pre- and post-insertion of three types of IUDs. Contraception. 1991;44(4):367-84.

92. Kingman CEC, Kadir RA, Lee CA, Economides DL. The use of levonorgestrel-releasing intrauterine system for treatment of menorrhagia in women with inherited bleeding disorders. BJOG Int J Obstet Gynaecol. 2004;111(12):1425-8.

93. Wellington K, Wagstaff AJ. Tranexamic acid-a review of its use in the management of menorrhagia. Drugs. 2003;63(13):1417-33.

94. Kadir RA, James AH. Reproductive health in women with bleeding disorders. World Federation of Hemophilia Treatment of Hemophilia Series No 48. 2009. http://ww.1.wfh.org/ publication/files/pdf-1206.pdf. Accessed 30 May 2017.
95. Bequignon E, Teissier N, Gauthier A, Brugel L, De Kermadec $\mathrm{H}$, Coste A, et al. Emergency Department care of childhood epistaxis. Emerg Med J. 2017;34(8):543-8.

96. Cocero N, Pucci F, Messina M, Pollio B, Mozzati M, Bergamasco L. Autologous plasma rich in growth factors in the prevention of severe bleeding after teeth extractions in patients with bleeding disorders: a controlled comparison with fibrin glue. Blood Transfusion. 2015;13(2):287-94.

97. Nurden P, Youlouz-Marfak I, Siberchicot F, Kostrzewa E, Andia I, Anitua E, et al. Use of autologous platelet-rich clots for the prevention of local injury bleeding in patients with severe inherited mucocutaneous bleeding disorders. Haemophilia. 2011;17(4):620-4.

98. Kouides PA. An update on the management of bleeding disorders during pregnancy. Curr Opin Hematol. 2015;22(5):397-405.

99. Huq FY, Kulkarni A, Agbim EC, Riddell A, Tuddenham E, Kadir RA. Changes in the levels of factor VIII and von Willebrand factor in the puerperium. Haemophilia. 2012;18(2):241-5.

100. Szecsi PB, Jorgensen M, Klajnbard A, Andersen MR, Colov NP, Stender S. Haemostatic reference intervals in pregnancy. Thromb Haemost. 2010;103(4):718-27.

101. James AH, Kouides PA, Abdul-Kadir R, Edlund M, Federici $\mathrm{AB}$, Halimeh $\mathrm{S}$, et al. Von Willebrand disease and other bleeding disorders in women: consensus on diagnosis and management from an international expert panel. Am J Obstet Gynecol. 2009;201(1):12.e1-.e8.

102. Makris M. Gastrointestinal bleeding in von Willebrand disease. Thromb Res. 2006;118(Suppl. 1):S13-7.

103. Randi AM, Laffan MA. Von Willebrand factor and angiogenesis: basic and applied issues. J Thromb Haemost. 2017;15(1):13-20.

104. Franchini M, Mannucci PM. Gastrointestinal angiodysplasia and bleeding in von willebrand disease. Thromb Haemost. 2014;112(3):427-31.

105. Castaman G, Federici AB, Tosetto A, La Marca S, Stufano F, Mannucci PM, et al. Different bleeding risk in type 2A and 2M von Willebrand disease: a 2-year prospective study in 107 patients. J Thromb Haemost. 2012;10(4):632-8.

106. Iannone A, Principi M, Barone M, Losurdo G, Ierardi E, Di Leo A. Gastrointestinal bleeding from vascular malformations: Is octreotide effective to rescue difficult-to-treat patients? Clin Res Hepatol Gastroenterol. 2016;40(4):373-7.

107. Bowers M, McNulty O, Mayne E. Octreotide in the treatment of gastrointestinal bleeding caused by angiodysplasia in two patients with von Willebrand's disease. $\mathrm{Br} \mathrm{J}$ Haematol. 2000;108(3):524-7.

108. Krikis N, Tziomalos K, Perifanis V, Vakalopoulou S, Karagiannis $\mathrm{A}$, Garipidou V, et al. Treatment of recurrent gastrointestinal haemorrhage in a patient with von Willebrand's disease with octreotide LAR and propranolol [7]. Gut. 2005;54(1):171-2.

109. D'Amato RJ, Loughnan MS, Flynn E, Folkman J. Thalidomide is an inhibitor of angiogenesis. Proc Natl Acad Sci USA. 1994;91(9):4082-5.

110. Engelen ET, van Galen KPM, Schutgens REG. Thalidomide for treatment of gastrointestinal bleedings due to angiodysplasia: a case report in acquired von Willebrand syndrome and review of the literature. Haemophilia. 2015;21(4):419-29.

111. Kohli D, Solomon S, Khatri N, Kessler C, Bull-Henry K. Lenalidomide as a novel therapy for gastrointestinal angiodysplasia. Am J Gastroenterol. 2013;108:S104.

112. Skaletz-Rorowski A, Kureishi Y, Shiojima I, Walsh K. The proand antiangiogenic effects of statins. Semin Vasc Med. 2004;4(4):395-400. 
113. Sohal M, Laffan M. Von Willebrand disease and angiodysplasia responding to atorvastatin. Br J Haematol. 2008;142(2):308-9.

114. Alikhan R, Keeling D. Von Willebrand disease, angiodysplasia and atorvastatin. Br J Haematol. 2010;149(1):159-60.

115. Makris M, Federici AB, Mannucci PM, Bolton-Maggs PHB, Yee TT, Abshire T, et al. The natural history of occult or angiodysplastic gastrointestinal bleeding in von Willebrand disease. Haemophilia. 2015;21(3):338-42.

116. Yaniv E, Preis M, Shevro J, Nageris B, Hadar T. Anti-estrogen therapy for hereditary hemorrhagic telangiectasia—a long-term clinical trial. Rhinology. 2011;49(2):214-6.

117. Yaniv E, Preis M, Hadar T, Shvero J, Haddad M. Antiestrogen therapy for hereditary hemorrhagic telangiectasia: a doubleblind placebo-controlled clinical trial. Laryngoscope. 2009;119(2):284-8.

118. Mehta J, Singhal S, Kamath MV, Mehta BC. A randomized placebo-controlled double-blind study of danazol in hemophilia A. Acta Haematol. 1992;88(1):14-6.

119. Kasper CK, Boylen AL. Poor response to danazol in hemophilia. Blood. 1985;65(1):211-3.

120. Botero JP, Pruthi RK. Refractory bleeding from intestinal angiodysplasias successfully treated with danazol in three patients with von Willebrand disease. Blood Coagul Fibrinolysis. 2013;24(8):884-6.

121. Berntorp E, Petrini P. Long-term prophylaxis in von Willebrand disease. Blood Coagul Fibrinolysis. 2005;16(Suppl. 1):S23-6.

122. Abshire T, Bowen J, Berntorp E. Von willebrand disease prophylaxis network. Haemophilia. 2011;17(3):558.

123. Abshire T, Cox-Gill J, Kempton CL, Leebeek FWG, Carcao M, Kouides P, et al. Prophylaxis escalation in severe von Willebrand disease: a prospective study from the von Willebrand disease prophylaxis network. J Thromb Haemost. 2015;13(9):1585-9.

124. Federici AB. Prophylaxis in patients with von Willebrand disease: who, when, how? J Thromb Haemost. 2015;13(9):1581-4.

125. Franchini M, Makris M, Santagostino E, Coppola A, Mannucci PM. Non-thrombotic-, non-inhibitor-associated adverse reactions to coagulation factor concentrates for treatment of patients with hemophilia and von Willebrand's disease: a systematic review of prospective studies. Haemophilia. 2012;18(3): e164-72.

126. Lethagen S, Kyrle PA, Castaman G, Haertel S, Mannucci PM, Auerswald G, et al. von Willebrand factor/factor VIII concentrate $\left(\right.$ Haemate $\left.{ }^{\circledR} \mathrm{P}\right)$ dosing based on pharmacokinetics: a prospective multicenter trial in elective surgery. J Thromb Haemost. 2007;5(7):1420-30.

127. Mannucci PO, Kyrle PA, Schulman S, Di Paola J, Schneppenheim R, Gill JC. Prophylactic efficacy and pharmacokinetically guided dosing of a von Willebrand factor/factor VIII concentrate in adults and children with von Willebrand's disease undergoing elective surgery: a pooled and comparative analysis of data from USA and European Union clinical trials. Blood Transfusion. 2013;11(4):533-40.

128. Hazendonk H, Fijnvandraat K, Lock J, Driessens M, van der Meer F, Meijer K, et al. A population pharmacokinetic model for perioperative dosing of factor VIII in hemophilia A patients. Haematologica. 2016;101(10):1159-69.

129. Ragni MV, Jankowitz RC, Chapman HL, Merricks EP, Kloos MT, Dillow AM, et al. A phase II prospective open-label escalating dose trial of recombinant interleukin-11 in mild von Willebrand disease. Haemophilia. 2008;14(5):968-77.

130. Ragni MV, Jankowitz RC, Jaworski K, Merricks EP, Kloos MT, Nichols TC. Phase II prospective open-label trial of recombinant interleukin-11 in women with mild von Willebrand disease and refractory menorrhagia. Thromb Haemost. 2011;106(4):641-5.

131. Ragni MV, Novelli EM, Murshed A, Merricks EP, Kloos MT, Nichols TC. Phase II prospective open-label trial of recombinant interleukin-11 in desmopressin-unresponsive von Willebrand disease and mild or moderate haemophilia A. Thromb Haemost. 2013;109(2):248-54.

132. Jilma B, Paulinska P, Jilma-Stohlawetz P, Gilbert JC, Hutabarat R, Knöbl P. A randomised pilot trial of the anti-von Willebrand factor aptamer ARC1779 in patients with type $2 \mathrm{~b}$ von Willebrand disease. Thromb Haemost. 2010;104(3):563-70.

133. Jilma-Stohlawetz P, Knöbl P, Gilbert JC, Jilma B. The anti-von Willebrand factor aptamer ARC1779 increases von Willebrand factor levels and platelet counts in patients with type 2B von Willebrand disease. Thromb Haemost. 2012;108(2):284-90.

134. Sundaram P, Kurniawan H, Byrne ME, Wower J. Therapeutic RNA aptamers in clinical trials. Eur $J$ Pharm Sci. 2013;48(1-2):259-71.

135. Nathwani AC, Tuddenham EG, Rangarajan S, Rosales C, McIntosh J, Linch DC, et al. Adenovirus-associated virus vector-mediated gene transfer in hemophilia B. N Engl J Med. 2011;365(25):2357-65.

136. Nathwani AC, Reiss UM, Tuddenham EG, Rosales C, Chowdary P, McIntosh J, et al. Long-term safety and efficacy of factor IX gene therapy in hemophilia $\mathrm{B}$. $\mathrm{N}$ Engl $\mathrm{J}$ Med. 2014;371(21):1994-2004.

137. De Meyer SF, Vandeputte N, Pareyn I, Petrus I, Lenting PJ, Chuah MKL, et al. Restoration of plasma von Willebrand factor deficiency is sufficient to correct thrombus formation after gene therapy for severe von Willebrand disease. Arterioscler Thromb Vasc Biol. 2008;28(9):1621-6.

138. Wang L, Rosenberg JB, De BP, Ferris B, Wang R, Rivella S, et al. In vivo gene transfer strategies to achieve partial correction of von Willebrand disease. Hum Gene Ther. 2012;23(6):576-88. 